\title{
A Contrastive Analysis Study Between English and Macassarese in Request Sentence
}

\author{
Sulastri \\ sulastri.sulastri@umi.ac.id \\ Rizkariani Sulaiman \\ riskarianisul@gmail.com \\ Universitas Muslim Indonesia
}

\begin{abstract}
This study examines the English and Makassar language request phrases. The imperative phrase of both languages from its form, purpose, and category in a sentence was studied in this analysis. The research used descriptive approach and contrastive analysis in terms of methods, the entire data were gathered by observing and interviewing the native speakers of Lakiung dialects who still speak in their everyday communication. In the analysis, the authors outlined and compared the differences and similarities in request sentences, classified and explained request sentences into subject, predicate, object and adverb. The results revealed that the request sentences in English and Macassarese have some similarities and differences were found in form of sentences and the function of adverb. The differences between English and Macassarese request sentence pattern, particularly on the element of predicate $(\mathrm{P})$ in a sentence. While the similarity was $\mathrm{S}-\mathrm{P}-\mathrm{O}-\mathrm{K}$ and $\mathrm{S}-\mathrm{P}$ construction.
\end{abstract}

Keywords: Contrastive Analysis, Request Sentences, English and Makassar Language

\section{Introduction}

People as social human need to communicate especially in daily affair and language is the most effective tool to communicate and convey one idea, feeling, thought and wishes. It has system, norms, and role that should be obeyed and the most important key to make a successful communication is people should make the other pleasant when saying something. To prevent a lot of difficulties in communication may appear because of dissimilarity of aspect of culture and behavior so people must know their language.

There are two distinct languages, English and Macasarese. While they are not in its family, but since a long time ago, the Macassarese language that comes from the Polynesian language family has been adopted as the regional language, it has been a contact medium for Macassarese tribes in South Sulawesi since a long time ago, and even before university students it was thought of in Primary School, Junior High School and Senior High School. This is mentioned in Chapter IV of the Constitution of 1945.

Makassar is one of the ethnic groups in Indonesia in South Sulawesi Province, Sulawesi island. Makassar has its own language, used not only by the people of Makassar, but also by other ethnic groups, such as Buginese, Mandarese, Torajanese.

The Macassarese reside along the Southern Sulawesi Peninsula, both Makassar and Buginese are the Malay group, compared to other Malay ethnic groups, they have a strong 
attitude very hard-tempered people. Besides Makassar town, they are Gowa, Takalar, Jeneponto, Bantaeng and Selayar district, there are some districts that speak Makassarese in South Sulawesi. Ethnic Makassar has its own writing alphabet, called "lontar" (Burhanuddin, 2012).

Considering the significance of English, the authors applies constrastive grammar, especially in request sentences, between English and Macassarese. People always find someone to do something in everyday affairs, but in making demands, a simple imperative must be respectful.

Ike Apriliana (2011) in her research entitle A Contrastive Study of Impeartive Sentence in English Javanese Language has conducted a research on the sentence in imperative can be positive or negative form. In positive imperative sentence, the speaker can be expressing it in request, command, invite, and give an advice to the listener.

In accordance with the background above, two research questions were drawn:

what are the pattern of request sentences in English and Makassarese also those function, (2) what are the differences and the similarities between English and Macassarese request sentence

The Research objectives are to know the the pattern of request sentences form in English and Macassarese and also those function, to discover the differences and the similarities between English and Macassarese request sentence. The authors hopes that this research will be useful for students to know regional language, especially to request sentences in English and Macassarese.

In South Sulawesi, there are differences and similarities between one area and another area in the Macassarese language dialect, so the authors limits the research only to discuss Lakiung dialects in the Gowa regency to prevent misinterpretation of the problem.

\section{REVIEW OF RELATED LITERATURE}

\section{The Definition of Request Sentence}

The imperative sentence or command are used to tell someone do something (Arifin, 2011). They are used to give orders or make request sentence it is very important in daily conversation, because as human being we have some shortcoming, so sometimes we need other people to help us. In asking somebody to do something we use imperative. Moreover, Joshi (2015) states that imperative sentences are also used to give instruction/advice/suggestion/invitation/appeal. It is used to make a request. The end of imperative sentence with period (.) or exclamation (!).

\section{The Form of Request Sentence in Macassarese}

The form of request sentence in Macassarese can be determined by looking at the verb and personal pronoun from those sentence.

Examples:
(1) Je'neko tetterek!
Take a bath soon!
(2) angtamakiq mae nenek!
Come in please, grandma!

Those sentences above (1) and (2) are Intransitive request sentence

(3) Ukiriqki arenta pak!

Please write down your name sir!

(4) Kanremaki

kanrejawata! 
Please, eat your cake!

Those sentences above (3) and (4) are transitive request sentence

\section{The Form of Request Sentence in English}

By using wiill / might, could, might you mind, would you mind not, I wonder if, do you mind, may / might, would / could, we can use sentence pattern of request.

Examples:

(5) Will you stay here with us any longer, please?

(6) Would you mind cleaning the room?

(7) Would you mind not smoking here?

(8) I wonder if you could lend me your money, please

(9) May I use your phone?

(10) Can I talk to you for moment?

\section{Variation of English Request}

There are some variations of English request sentence, it will be described as follows:

1. Request for advice

You had better take of you wet coat

You must read this book

2. Request for permission

Can I read your magazine?

MightI borrow your ruler?

3. Request for order

How shall I cook it?

Where shall we put this newspaper?

4. Request for suggestion

Shall we be here tomorrrow?

Shall we meet at the theatre?

\section{METHOD}

This section described research design, population and sample, procedure of collecting data and technique of analysis data. The authors used descriptive technique and contrastive analysis to reveal the differences between English and Macassarese request sentences. The technique was used because two distinct languages having distinct grammatical features are English and Macassarese. To recognize the differences and similarities between English and Macassarese in the grammatical aspects. Contrastive analysis is the systematic study of a pair of languages with a view to identify their structural differeces and similarities. Historycallay it has been used to establish language genealogies (Wikipedia, 2018)

The authors observed the native speakers Lakiung dialect spoken in their conversation consisting of twelve (12) people by taking the details and knowledge from this research. In the Gowa regency in Romangpolong village, they have common individuals.

The kinds of data was collected in this research include as primary data which was taken from the native speakers of lakiung dialects who always speaks in their daily communication

Observation was used to describe the language 's goal, next, by analyzing the free conversation of native speakers in any place by hearing it. As for the interview, in taking correct details, it was achieved by keeping conversations face to face. Elicitation is the 
questions that the respondents were asked as native speakers of the local language and written in Indonesian. The list of words were given to be translated and stated into local language.

\section{FINDINGS AND DISCUSSION}

a. The elements of request sentences in Macassarese :

1. Pattern : S - P - O - K (Subject - Predicate - Object - Adverb)

$\frac{\text { Syakila }}{\mathrm{S}} \frac{\text { erangi }}{\mathrm{P}} \frac{\text { boqbonu }}{\mathrm{O}} \quad \frac{m u k o}{\mathrm{~K}}$

(Syakila brings your book tomorrow)

2. Pattern: $\mathrm{S}-\mathrm{P}$

Tena ni paqbeangko mempo

( you are not allowed to sit)

3. Pattern : $\mathrm{P}-\mathrm{S}-\mathrm{O}$

$\frac{\text { Ngiringko surak }}{\mathrm{P}}$

(You send a letter)

4. Pattern : $\mathrm{P}-\mathrm{O}-\mathrm{S}$

$\frac{\text { Abbaca }}{\mathrm{P}} \frac{\text { majallako }}{\mathrm{O} \quad \mathrm{S}}$

5. Pattern : P - S

Angngukiriko

$\mathrm{P} \quad \mathrm{S}$

(you write)

b. The elements of request sentences in English :

1. Pattern : S - P-O - K (Subject - Predicate - Object - Adverb)

$\frac{\text { Ariq }}{\mathrm{S}} \frac{\text { puts }}{\mathrm{P}} \frac{\text { your book }}{\mathrm{O}} \frac{\text { on the table. }}{\mathrm{K}}$

2. Pattern: $\mathrm{S}-\mathrm{P}$

The letter contained exciting

$\mathrm{S} \quad \mathrm{P}$

3. Pattern : $\mathrm{P}-\mathrm{O}$

Hang the picture, please

$\mathrm{P} O$

4. Pattern : $\mathrm{P}$

Drink, please

$\mathrm{P}$

The authors can learn the differences and similarities between the form of request sentences in English and Macassarese, based on the data presented above. The variations that we saw from the position of the subject. In Macassarese, the position of subject was flexible, they could change into POS, PSO, PSK without changing the meanng. While in English the position of subject was stable. Besides that the position of subject in request sentences in Macassarese was a bound form (pronominal affixI which directly combining with the predicate (verbal). In request sentences in English there was no functional pronominal affix sticks on the verb. Whereas, the similarities in the element of sentences $\mathrm{S}-\mathrm{P}-\mathrm{O}-\mathrm{K}$ and S 


\section{The Degree of Politeness Request Sentences in Macassarese}

For the second person in the singular form consists of $k o, k i$, mako, maki in Macassarese personal pronoun, they are divided into two groups based on their $k o$ degree of politeness and impoliteness, mako are classified as impolite form of personal pronoun, while $k i$, maki, are polite fom. But in English, in the singular form, the pesonal pronoun for the second person is you only

The politeness degree in constructing request sentence influenced by the use of personal pronoun illustrated in the following examples :
Gassing : Mangeki Jappa-jappa
(Let's take a walk)
Basse : Iye sinampepi
Baco : Mangemaki anjama (Let's go to work)
Sangkala : Iye sinampepi
Gassing : Mngemako anjoeng
Basse : Iyo, tayangi rolong
( Let's go there)

The use of personal pronoun $-k i$ in the sentence mangemaki jappa can be regarded as the main element in constructiing the sentence to be polite. It has the same function as word 'please' in English. And 'iye' means ' $y e s$ ' in the answer for polite request in macassarese and 'iyo' is the answer for impolite request. Generally the use personal pronoun '-ki', 'maki' used when we are talking with the people whomis older than us, for example our parents, personal pronoun - ko, -mako used when we are talking with the people who is younger than us or the same age.

Furthermore, there are three status in Macassarese, they are:

1. Affirmative status
a. ' $k o$ '
Assompako
b. 'nga'
(Take a payer)
Alleanga jene inung
( Give a glass of water)
c. -sipaka - - ko'
Sipakaingako riparanu tau
( remind each other of human being)
Sipakalabbiangko riparannu pasikolang
(Appreciate each other with your classmate)
Sipakarannuko sipammanakang
(Have fun with your family)

2. Negative status

'tena'

Tena nipabbeangko tinro baribbasa

(you are not allowed to sleep in the morning)

Tena kulle assandala antamarimasigika

(you are prohibited to use slippers enteringthe mosque)

3. Status Interrogative

'ero (ki)'

Eroki aganga mange ripasara

(could you accompany me to go to the market?)

Eroki tolonga

(Would you help me?)

Request sentences from certain status affirmative status part 'a' is request advice 'in Macassarese, part' b 'was request for orders' and part' c 'was request for suggestion'. Negative 
status request sentence was 'request for advice', whereas in interrogative status was 'request for orders'.

\section{Discussion}

\section{The Function of Request in Macassarese and English}

a. Request sentence which contains $\mathrm{S}-\mathrm{P}-\mathrm{O}-\mathrm{K}$

Request sentence which contains $\mathrm{S}-\mathrm{P}-\mathrm{O}-\mathrm{K}$ generally we found in Macassarese and in English,e,g. :

\section{Macassarese}

(1) Basse allei passassang ri pangangaloang!

Basse takes the laundry at the clothesline

(2) Lina boliki doeknu ri bang!

Lina saves your money at the bank!

\section{English}

(3) John, please move your hat in the theatre!

(4) You, put your hands on the table!

From those sentences (1), (2), (3) and (4) indicated that those sentences is imperative which directly referring towards subject was implementers of imperative. Those sentences analyzed based on it's functional structure as follows:

(1) $\frac{\text { Basse }}{\mathrm{S}} \frac{\text { allei }}{\mathrm{P}} \frac{\text { passassang }}{\mathrm{O}} \frac{\text { ri pangangaloang! }}{\mathrm{K}}$

(2) John, please remove your hat in the table!

$\mathrm{S} P \mathrm{O}-\frac{\mathrm{K}}{\mathrm{P}}$

The structure in Macassarese sentences (1) and (2) that their subject was free noun (Basse and Lina) its predicate was ended by suffix pronominal as a sign of subject then followed by object and adverb. Where is imperative in English (2) if the subject is the single name (John) subject and predicate is limited by comma (,)

b. Request sentence which contains $\mathrm{P}, \mathrm{O}, \mathrm{S}$, and $\mathrm{K}, \mathrm{P}, \mathrm{O}, \mathrm{S}$

Macassarese

(3) $\frac{\text { Erangi }}{\mathrm{P}} \frac{\text { anjo }}{\mathrm{O}} \frac{\text { karanjenga }}{\mathrm{O}} \frac{\text { Basse sinampe! }}{\mathrm{S}} \frac{\text { s }}{\mathrm{K}}$

Basse, bring the basket later!

(4) $\frac{\text { Muko }}{\mathrm{K}} \frac{\text { tebbakko }}{\mathrm{P}} \frac{\text { anjo bunga kalotoroka }}{\mathrm{O}} \frac{\text { nak! }}{\mathrm{S}}$

Son, tomorrow cut the dried flower!

English

(5) $\frac{\text { Shoot }}{\mathrm{P}} \frac{\text { the bird directly! }}{\mathrm{O}} \frac{\mathrm{K}}{\mathrm{K}}$

(6) $\frac{\text { Slowly, push }}{\mathrm{K}} \frac{\text { the switch, please! }}{\mathrm{P}}$

Request which contains $\mathrm{P}, \mathrm{O},(\mathrm{S}), \mathrm{K}$ and $\mathrm{K}, \mathrm{P}, \mathrm{O}, \mathrm{S}$ generally we found in Macassarese (e.g 3 and 4). Whereas in English the subject could be vanished, except the speaker explained to whom the convey request. In Macassarese subject which refers to the people's name (Basse) or (nak) was written if the status of speaker who mentioned those sentence is higher.

In example (5) and (6) indicated that adverb in English not only be placed at the end or after object but also could be placed at the first sentence. In other word the position of adverb in English could be changed, at the first or the end of request sentence. 
c. Request sentence which contains $\mathrm{P}, \mathrm{S}$ and $\mathrm{P}$

Request sentence which contains $\mathrm{P}, \mathrm{S}$ and $\mathrm{P}$ could be seen at the example as follows:

(7) $\frac{\text { Bangungko }}{\mathrm{P} \quad \mathrm{S}}$

(8) $\frac{\text { Get up }}{\mathrm{P}}$

In sentence (7) and (8) were transitive request sentennce form. It has been explained before that intrasitive request sentences could not be extended by adding adverb. Examples:

(7a) Bangungko tettereq!

$$
\mathrm{P} \quad \mathrm{S} \mathrm{K}
$$

(8a) $\frac{\text { Mangemako anjoeng }}{\mathrm{P} \quad \mathrm{S}} \frac{\mathrm{K}}{\mathrm{K}}$

In sentence (7) we saw suffix pronominal after predicate. Suffix pronominal has subject sentence function, whereas in English (8) did not find such form.

In sentence (7a) and (8a) suffix pronominal $-k o$ (as singular second person), $-m a k i$ (plural second person), -kiq (plural second or third person), as subject which is binding at each verb. Even though, subject was not binding but could be mentioned that personal name or tittle was placed after predicate, suffix pronominal. Suffix that refers to subject or person's name or tittle is the identification of Macassarese request sentences.

If we took note of the predicate function, particularly in the request sentence in Macassarese and English, the authors concluded that it was very important to have this function. One predicate may also be used in the English request statement. The request sentence consisting only a predicate was a full sentence, although the sentence has not yet completed from the aspect of the sentence structure. These phrases are referred to as minof sentence since they consist only of predicate

\section{The Function of Object}

The object is the logical entity that the predicate completes. The use of the object in the sentence of the request will make certain sentences understandable. Both sentences were instances of the request statement for the object as follows:

Macassarese

(9) $\frac{\text { Sare ko Jangang }}{\mathrm{P}}$ S $\frac{\text { kanre ri karuang! }}{\mathrm{O}}$

Feed the chickens in this afternoon!

(10) $\frac{\text { Kanreko }}{\mathrm{P} \quad \mathrm{S}} \frac{\text { paqbale }}{\mathrm{O}} \frac{\text { pintallu siallo! }}{\mathrm{K}}$

Take the medicine three times a day!

(11) $\frac{\text { Teako baluki }}{\mathrm{P} \quad \mathrm{S}} \frac{\text { anjo ballanu! }}{\mathrm{O}}$

Don't sell your house!

(12) Timbanaki je'ne ri quabang!

$\mathrm{P} \mathrm{S} \quad \mathrm{O} \quad \mathrm{K}$

Take the water in the jar!

English

(14) $\frac{\text { Adjust the carburetor! }}{\mathrm{P}} \frac{\mathrm{O}}{\mathrm{O}}$ 
(15) $\frac{\text { Do not reverse }}{\mathrm{P}} \frac{\text { the bolt with pliere! }}{\mathrm{O}}$

From sentences (09), (10), (11), (12), (13),(14) and (15) gave description about the function of object which explained predicate.

In request sentence in Macassarese and English the function of object occupied different position. In Macassarese, the function of object was placed after subject except in prohibition sentence (11), the function of object was placed after predicate. The function of object the authors meant pronominal such as -kiq (singular second person), -maki (plural second person or plural third person), whereas in English, the function of object was placed after predicate from transitive verb.

\section{The Function of Adverb}

The adverb feature was very different from the object, and its position after the predicate was obvious. The position of the adverb was flexible in the request sentence, otherwise it may be put at the first, middle and end of the sentence.

Example:

Macassarese:

(16) $\frac{\text { Erangko }}{\mathrm{P} \quad \mathrm{S}} \frac{\text { pulupeng }}{\mathrm{O}} \frac{\text { muko! }}{\mathrm{K}}$

Bring your pen tomorrow!

English:

(17) $\frac{\text { Ani, }}{\mathrm{S}} \frac{\text { put }}{\mathrm{P}} \frac{\text { your book }}{\mathrm{O}} \frac{\text { on the table! }}{\mathrm{K}}$

The position of adverb at both sentence at the end of sentence look another, examples:

Macassarese:

(18) $\frac{\text { Muko }}{\mathrm{K}} \frac{\text { erangko pulupeng! }}{\mathrm{P} \text { S }}$

(19) Erangko suko pulupeng!

$$
\mathrm{P} \text { S } \mathrm{K} \text { O }
$$

English:

(20) on the table, Ani put your book!

$\mathrm{K} \quad \mathrm{S} \quad \mathrm{P} \quad \mathrm{O}$

(21) Ani, on the table, put your book!

$\begin{array}{llll}\mathrm{S} & \mathrm{K} & \mathrm{P} & \mathrm{O}\end{array}$

From sentences (16) and (17) the position of adverb at the end, whereas (18) and (20) the position of adverb at the first and (19) and (21) the position of adverb in the middle of sentence

Besides, the form of those sentence above in request sentence either in Macasserese or in English, there are four kinds of adverb.

\section{The Usage of a Request in Macassarese}

Previously, it has been explained that personal pronoun in Macassarese $-k o$ (singular second person), -maki, -mako (plural second person). Personal pronoun $-k o$, -mako, in Macassarese sentences are indicated of impolite form whereas personal pronoun $-k i$ or $-m a k i$ were classified as politeness

The authors gave some examples in using request sentences of Macassarese such as request for advice, permission, orders, and offers as follows : 
a. Request for advising

How to give advice for someone else

(22) Appilajarako!

You study hard!

(23) Mantangko ri ballak appilajarak

Stay at home to study!

(24) Mange maki assambayang!

Please, go to pray!

In addition, those sentences, including prohibition, suggestion and request for advice. Because of the practical affix that sticks on the noun, those sentences above were impolite sentences. The functional affix were $-k o$, - mako. They used when speaker were the same age or his/her social degree is higher than interlocutor, whereas $-k i$, -maki used to the person which older than us. For example our parents, older brother, etc.

b. Request for ordering

Prefix ' $t a$ ' changing the value impolite sentence into polite without changing the meaning whereas the usage of ' $t a$ ' in possessive form as follows:

(25) Nia arotta tolonga?

Would you mind to help me?

(26) Alleangnga handuq!

Please, give me towel!

Those sentences contained ' $n g a$ ' which has 'help' meaning. Those sentence is more complete than other Macassarese request sentences.

c. Request for Permission

Sentences that used in Macasserese for stating permission was 'tabeq' or in English 'excuse me'

(27) Tabeq je'neta

Excuse me! Pass the water!

(28) Tabeq panneta

Excuse me! Give me plate!

d. Request for offers

(29) Eroki nganre kanre jawa?

Would you mind eating cake?

(30) Eroki mange lampa njoeng?

Would you go there?

In fact, request sentences in Macassarese particularly polite sentences is quite different with request sentences in English. In English, request sentences follows the rule whereas in Macassarese was flexible.

For determining, the degree if politeness was defined intonation of the speaker Betty Schrampher Azar (1981:146) states that the degree of politeness, however, is often determined by the speaker's tone of voice.

Based on the definition above, absolutely that was occupied an important role in request sentences particularly the degree of politeness in the intonation of the speaker himself/herself.

About the politeness in speaking, sometimes people still do not care, the most important thing the talking point which was spoken by the speaker received by the interlocutor. As a matter of fact the politeness in speaking describes our attitude toward other people. 
The politeness in speaking usually influenced a social status. Rich social status is different with poor social status in speaking, between superior and subordinate.

The differences between the degree of politeness in English and Macassarese in request sentence besides intonation or tone, the existence of auxiliaries such as 'could', 'should', 'would' and 'please'. While in Macassarese besides intonation, also the functional of affixes pronominal which stick in the verb, such as '-ki', '-ko', '-maki', '-mako', '-ta', '$n g a$ ', because in English, there are not any functional affix (pronominal).

\section{CONCLUSION}

In accordance with the description of results and discussion, it could be concluded that the term pattern S-P-O-K was flexible in the Macassarese request, it could be changed into P-S O, K-P-O-S and P-S-O, this pattern was a constant one, the pattern did not change. The adverb in the sentences of the Macassarese request appears in all positions of a sentence, in the initial position, middle position and final position, while the adverb in the sentence of the English request appears only in the sentence in the initial and final position of a sentence

The differences between English and Macassarese request sentence pattern, particularly on the element of predicate $(\mathrm{P})$ in a sentence. While the similarity was $\mathrm{S}-\mathrm{P}-\mathrm{O}-$ $\mathrm{K}$ and $\mathrm{S}-\mathrm{P}$ construction.

The authors delivered some suggestions from this analysis for individuals who are interested in performing the experiment in the same area. Here is the recommendation as follows : (1) the authors want language learners to continue to contribute to the life of the local language by the language researcher on rational languages or vernaculars; (2) for the university, the authors suggests that the university involved in government should patiently offer help, encouragement, direction to students in the institution

\section{REFERENCES}

Azar, Betty Schrampher. 1993. Understanding and Using English Grammar. The second edition. Prentice-Hall,Inc.

Burhanuddin. 2012. Makassar Indonesia, The Historical City. Fakultas Sastra UMI. Tamaddun Journal. ISSN 0216-809. Vol. 10, No.2 Desember 2012.

Davison, A. (1984). Syntactic markedness and the definition of sentence topic. Language, 797-846.

Dinas Kebudayaan dan Pariwisata Sulawesi Selatan. 2002. Ensiklopedia Sejarah Sulawesi Selatan. Makassar : Dinas Kebudayaan dan Pariwisata Sulawesi Selatan.

Halijah, S., Ratnawati, R., \& Ratnasari, R. (2016). The Ability of Course Students and Non Course Students at SMPN 19 Moncongloe in Reading Comprehension. Tamaddun, 15(2), 89-98.

Ike Apriliana, Ernawati. 2011. A Contrastive Study of Imperative Sentence in English and Javanese Language. Thesis. (http://www.core.ac.uk/display/34220210). Accessed in 2011.

Jannah, H., Ratnawati, R., \& Fatimah, S. (2017). The Description and Meaninings of Proverbs To-Riolo of Buginese Tribe in South Sulawesi (A Semantical Analysis). Tamaddun, 16(1), 4-12.

Joshi, Manik. English Imperative Sentences: Most Common Imperative Verbs. 2015. (http://www.lulu.com/manik-joshi/english-imperative-sentences-most). Accessed on August 06, 2018.

Keshavarz, M. H. (2015). Contrastive Analysis, Error Analysis and Interlanguage. Tehran: Rahnama Press. 
Ratnawati, R., Sumirna, S., \& Isma, H. N. (2019). A Study on the Correlation between Motivation and Students' Speaking Performance at an Indonesian Vocational High school Context. ELT WORLDWIDE, 6(2), 171-180.

Rosmiaty, R., Ratnawati, R., \& Latukau, H. (2019). Students' Ability in Using Direct and Indirect Speech of English Department Students at Universitas Muslim Indonesia. ELT WORLDWIDE, 6(1), 73-82.

Wahid, Sugira, Hj. Prof.Dr. 2007. Manusia Makassar. Makassar : Refleksi 